\title{
On the Legal Methods for Foreign Shareholders to Withdraw from Sino-Foreign Joint Ventures
}

\author{
Shu-Xue Jia ${ }^{1}$ \\ ${ }^{1}$ Law School of Qingdao University of Science and Technology, P. R. China \\ Correspondence: Shu-Xue Jia, Law School of Qingdao University of Science and Technology, Qingdao City \\ 266061, Shandong Province, P. R. China. Tel: 86-137-0895-9311. E-mail: jiashuxue@deheng.com.cn
}

Received: May 20, 2014 Accepted: July 21, 2014 Online Published: August 15, 2014

doi:10.5539/ass.v10n18p85 URL: http://dx.doi.org/10.5539/ass.v10n18p85

\begin{abstract}
Recent years have witnessed a growing number of Sino-foreign Joint Ventures from which the foreign shareholders are willing to withdraw. There are two methods available for shareholders to withdraw from a joint venture according to the Chinese laws and regulations: namely equity transfer and corporate dissolution. Foreign shareholders should take into account the company's specific situation and the goals and effectiveness they want to achieve when deciding on the best way to withdraw. Usually equity transfer is deemed to be the first choice.
\end{abstract}

Keywords: foreign shareholder, Sino-foreign joint venture, equity transfer

Sino-foreign Joint Venture is the earliest investment method by foreigners, covering the largest number of foreign-invested companies in China (Chen, 1998). Following the evolution of China's policy on foreign investment the difference of treatment between domestic enterprises and foreign enterprises has been diminishing. Moreover, with a deepening understanding of China's domestic environment it's not wholly necessary for foreign investors to depend on Chinese parties to achieve their development goals in China anymore (Ye, 2010). Furthermore, different business philosophies and the different management style originated therewith, plus conflicts arising from the distribution of dividend lead to difficulties and severe inefficiency in making business decisions. Meanwhile, the abuse of foreign parties' Intellectual Property rights (hereinafter referred to as IPs) and lack of effective protection thereof happened frequently. Under such circumstances a suitable way to withdraw from the original joint venture, taking into account the time to be consumed, costs to be incurred and the legitimacy of the withdrawal process, has become the first consideration of some foreign shareholders of Sino-foreign joint ventures (Chen \& Tian, 2011).

\section{Analysis on the Advantages and Disadvantages of Methods for Foreign Shareholders to Withdraw from a Sino-Foreign Joint Venture}

There are two methods for foreign shareholders to withdraw from a joint venture: namely equity transfer and corporate dissolution. Foreign parties should select the method which can to the biggest extent save costs and time (Xu, 2011).

\subsection{Equity Transfer}

Equity transfer means the shareholder transfers his or her equity to others according to law or the company's bylaw (Chen, 1995).

\subsubsection{Transfer to Original Internal Shareholders}

According to the first paragraph, Article 72 of the Company Law of China (Note 1) "shareholders of a limited liability company may transfer their all or partial equity to the other shareholders of the company all". The law doesn't lay any restriction on such transfer of equity because it doesn't affect the closeness of the limited company, as long as both parties reach the agreement on relevant issues such as the equity proportion to be transferred, price and time etc.

\subsubsection{Transfer to Outsiders}

According to Article 20 of the Regulations for the Implementation of the Law on Sino-foreign Joint Ventures (Note 2), "In case one party to the joint venture wants to transfer all or partial investment in the venture to a third party, this party must obtained consent from the other party to the joint venture, and an application for the equity 
transfer must be submitted to the examination and approval authority for approval. Afterwards this change shall be registered with the registration and administration office. In case of such transfer of equity by one party, the other party has pre-emptive right. The conditions for the transfer of equity to a third party shall not be more favorable than those offered to the other party to the joint venture. No transfer shall be made effective should there be any violation of the above stipulations." So, in comparison with equity transfer among original shareholders the regulations, to maintain the closeness of the company, the reliance between shareholders and the smooth running of the business (Yang, 2002), the regulations lay much restrictions and conditions on the transfer of equity to outsiders, which means difficulties in and obstacle to the transfer of equity in some cases.

\subsubsection{Compulsory Transfer of Equity}

In reality what frequently happens is that one shareholder neither consents to another shareholder's equity transfer to outsiders nor agrees to buy the equity (Yu, 2008). To provide a channel for shareholders to withdraw investment under such circumstances the laws made the following provisions.

The second paragraph of Article 72 of the Corporate Law provides as follows:

"If a shareholder wants to transfer his/its equity to anyone who is not a shareholder of the company, the transfer is subject to the consent from more than half of the other shareholders. A written notice about the transfer of equity shall be given to the other shareholders for their consent. If any of the other shareholders fails to reply within 30 days upon the receipt of the written notice, it shall be deemed to have consented to the transfer. In case no consent by half or more of the other shareholders to the transfer is obtained, the shareholders who disagree to the transfer shall purchase the equity to be transferred. Otherwise, they shall be deemed to have consented to the transfer. Under the same conditions, the other shareholders have a preemptive right with respect to the purchase of the equity to be transferred. If two or more shareholders claim the preemptive right, their respective purchase percentage shall be determined through negotiation. In case no agreement is reached, their respective percentage shall be determined according to the percentage of their capital contributions percentage. In case it is otherwise provided for the transfer of equity in the bylaw, the bylaw prevails."

Article 10 of "the Provisions on Various Issues Concerning the Trial of Cases Involving Disputes Relating to Foreign Invested Enterprises (1)" (Note 3) by the Supreme Court of China made the following provisions:

"If one party of a foreign-invested enterprise wants to transfer all or part of his (its) equity to a third party other than the shareholders, he must obtain the consent from all the other shareholders. If any other shareholder requests to revoke the equity transfer contract on the ground of lack of his consent, the people's court shall uphold such request, unless under any of the following circumstances:

1) There is evidence showing that the other shareholders have consented to the transfer;

2) A written notice about the equity transfer had been given, but the other shareholders didn't give a reply within 30 days upon receipt of the written notice; or

3) The other shareholders neither consent to the transfer nor agree to purchase the involved equity."

Though the provisions are simple and clear difficulties can still be foreseen in practice. Where the other shareholders neither consent to the transfer nor agree to purchase the involved equity, though it is provided that this "shall be deemed to have consented to the transfer", in reality it's difficult to accomplish relevant process concerning the change of shareholders (Liu \& Gao, 2010). According to relevant rules upon applying for approval by the Department of Commerce and registration with Industrial and Commercial Agencies new documents including a new joint-venture agreement, the new Articles of Association etc. must be submitted. However, in the event that the Chinese party disagree to the equity transfer at all; it's almost impossible for them to cooperate with the foreign shareholder and the third party to accomplish all these procedures.

Therefore, the value of the provision "shall be deemed to have consented to the equity transfer" has to be realized through litigation. That is to say the transferee has to file a lawsuit against the company and involved shareholders so to get a verdict ordering them to perform their obligations cooperating to accomplishing the transfer procedures, especially the modification of the corporate registration. A lawsuit will increase the cost of equity transfer, and moreover, the equity transfer to a third party achieved through litigation possibly damaged the reliance previously existing among shareholders which is crucial to the operation of a joint venture as closed limited liability company (Liu \& Gao, 2011).

\subsection{Dissolution of the Venture}

\subsubsection{Dissolution Situations Prescribed by Law}

According to article 90 of the Regulations for the Implementation of the Law on Sino-foreign Joint Ventures a 
joint venture may be dissolved under the following circumstances:

1) Duration of the company terminates;

2) Unable to continue operations because of heavy losses;

3) Unable to continue operations because one of the contracting parties fails to fulfill the obligations prescribed by the agreement, contract and bylaw;

4) Unable to continue operations because of heavy losses caused by force majeure including natural calamities and wars, etc.;

5) Inability to achieve the desired objectives of the operation and to see a future for development meanwhile;

6) Occurrence of other reasons for dissolution prescribed by the contract and articles of association.

In cases of (2), (3), (4), (5) and (6) of the preceding paragraph, the board of directors shall apply for dissolution with the examination and approval authority; in case of (3), the party performing the contract shall apply with the examination and approval authority.

Under the circumstance described in (3) of this article, the party that failed to fulfill the obligations prescribed by the agreement, contract and bylaw shall be liable to the losses thus caused.

\subsubsection{Apply for Compulsory Dissolution}

According to article 183 of the Company Law of China, where a company meets any serious difficulty in its operations or management so that the interests of the shareholders will face heavy loss if the company continues to exist and the difficulty cannot be solved by any other means, the shareholders who hold ten percent or more of the voting rights of all the shareholders of the company may plead the people's court to dissolve the company.

Accordingly the "Provisions on Various Issues Concerning the Application of 'Corporate Law of China' by the Supreme People's Court (1)" (Note 4) provided situations in detail where compulsory dissolution can be applied for. According to Article 1 of the Provisions, if any shareholder that individually or jointly with other shareholders holds $10 \%$ or more of the voting rights of all shareholders of a company initiates a corporate dissolution action for any of the following reasons and the provisions of Article 183 of the Corporate Law are complied with, a people's court shall accept such action:

1) The company has been unable to hold a meeting of shareholders or a general meeting of shareholders during a period of two consecutive years or more and the business of the company gets into great trouble; or

2) Because a statutory quorum or a quorum specified in the bylaw of the company cannot be present at the time of voting by shareholders, a meeting of shareholders or a general meeting of shareholders has not been able to adopt any valid resolution during a period of two consecutive years or more, and the business of the company gets into great trouble; or

3) Perpetual disagreement among directors of the company cannot be solved through meetings of shareholders or general meetings of shareholders and the business of the company gets into great trouble; or

4) The business of the company gets into other great difficulties and the continued existence of the company will cause great loss to the shareholders.

5) Where any shareholder of a company initiates a corporate dissolution action on the grounds that his interests such as the right to know and the right to request dividend distribution has been harmed, or that the company suffers losses or its property is inadequate to pay off all its debts, or that the company has not gone through the liquidation proceedings after the business license has been revoked and on other grounds, a people's court shall accept the action.

Though dissolution is a practical alternative under various situations, to protect creditors' interests and both parties' benefits relevant law and regulations prescribe cumbersome procedures for such dissolution (Liu \& Gao, 2010). Besides the examination by approving authority and auditing by tax authorities, a whole series of writing-off procedures are also requested of by the customs, financial, industrial and commercial agencies etc. Moreover, during the dissolution process, where the liquidation group finds that the company has been lack of ability to offset debts with its assets a bankruptcy proceeding must be filed with the court, which no doubt makes the dissolution more time-consuming (Ye, Liu, \& Ma, 2010). Therefore, only in circumstance where neither parties want to continue to operate the joint venture or the foreign party fails to transfer his (its) equity and find other ways to withdraw the approach of dissolution may be considered. 


\section{The Best Way for Foreign Shareholders to Withdraw from a Joint Venture: Equity Transfer through Consultation}

Through the analysis on different approaches for withdrawal from a joint venture we can conclude that equity transfer through consultation shall be the best choice, from whatever aspect to be assessed.

\subsection{Low Time Cost}

There is no time limitation laid by law with respect to equity transfer among shareholders. Though time taken to reach an agreement between two parties regarding the transfer of equity differs with respect to different companies, so long as the requested documents are prepared well time for examination and approval by the competent authorities will not exceed the reasonable period prescribed by law (Chen, 2005). If all goes smoothly the equity transfer can be accomplished within three to four months. Compared to compulsory dissolution by court this approach substantially reduces the time cost.

\subsection{Low Expense}

If both parties can come to the agreement on equity transfer, the costs for the following procedures such as the examination, ratification and registration modification etc. by relevant authorities and agents are very low. Moreover, equity transfer through consultation means less working hours by lawyers and accountants shareholders have to pay for.

\subsection{Less Hardship}

The transfer of equity, no matter to a third party or internal shareholder, is much easier to achieve through the method of consultation, compared with dissolution, a method which leaves no other choice to the other side other than liquidating the company (Zhong, 2006). Where the foreign shareholder transfers the equity to the original Chinese shareholder the whole process will be accomplished smoothly and timely if both parties come to an agreement with respect to the transfer conditions. Where the foreign shareholder transfers the equity to a third party upon consent by the original Chinese shareholder the third party, who will be the new shareholder of the company, is usually welcomed by the company. In fact, under most circumstances such third party is the one that the Chinese shareholder had consulted with and appointed, which guaranteed the equity transfer to be conducted smoothly thereafter (Wang, 2008).

\subsection{Easier Approval}

All credits and debts will be born by the existing company, in which only the shareholder changed, so the ratification authority has no excuse to worry about any debt or other liabilities left with no body to assume. So long as the transfer of equity is legitimate with respect to the form of transfer it usually can be approved rapidly.

\section{Several Issues the Foreign Shareholder Should Pay Attention to While Withdrawing from a Joint Venture through Transferring Equity}

\subsection{Look for Suitable Transferee}

To withdraw from a joint venture through transferring equity the key point is to seek a suitable transferee. Where the Chinese shareholder of the joint venture wants to buy the equity of the foreign shareholder, due to the long period of cooperation between both parties it will be relatively easier to agree on the transfer in respect of price and the other terms. However, if the original Chinese shareholder has no willingness to accept the equity to be transferred, to seek a suitable third party is deemed to be the most important issue. The equity transfer to a third party other than an original shareholder means to reorganize the original joint venture as a limited liability company. Due to the closeness of a limited liability company it is not an easy matter to make the original shareholder to accept a third party as a new shareholder, especially in case the original Chinese shareholder holds an inconsistent attitude towards the transfer of equity (Zhao \& Liu, 2002). If the original Chinese shareholder refuses to accept a third party as a new shareholder appointed by the foreign shareholder all procedures concerning the equity transfer, such as the ratification and registration etc. will be difficult to accomplish, and the object to withdraw from the joint venture through equity transfer will not be able to achieve. Under such situation the best approach is to find a strong third party which has the capacity through negotiation to make or even press the original Chinese shareholder to cooperate by taking advantage of its advantageous conditions such as government-funded background and market dominance etc.

\subsection{The Issue of Intellectual Property}

During the transfer of his equity the foreign shareholder should also make proper arrangement for the IPs he owns. It is suggested that foreign shareholder sign an agreement regarding the use of IPs with the new company, either to continue or terminate the license for the IPs. 


\subsection{The Issue of Corporate Name}

If the name of the joint venture bears element relating to foreign shareholder's trade mark the foreign shareholder should negotiate with the Chinese shareholder and decide whether to request of the change of the corporate name.

\section{References}

Bian. (2012). On the regulatory approval of equity transfer by foreign-funded enterprises. People's Judiciary, 7. Retrieved from http://www.110.com/ziliao/article-349430.html

Chen. (1995). Analysis on various issues concerning the transfer of equity of foreign-invested enterprises. People's Judiciary, 6, 15-19.

Li. (2008). Confirmation and transfer of equity of foreign-funded enterprises. People's Judiciary, 13, 101-106.

Liu, Y. (2010). The new development trend of foreign-funded enterprises. Law Application, 8, 94-105.

Liu. (2008). Company law, Beijing. BJ: Beijing University Press.

Liu. (2011). On the administrative approval and contractual effect-Based on the equity transfer of foreign-funded enterprises. China Law, 2, 76-81.

Liu. (2011). Practice of Corporate Litigation, Beijing. BJ: China Legal Publishing House.

Mao. (2010). Explanation on several difficult issues concerning the equity transfer of foreign-funded enterprises. Study on Legal System, 10. Retrieved from http://www.chinalawinfo.com/LawOnline/ArticleFullText.aspx? ArticleId $=57800$ \&listType $=0$

Sui. (2010). Legal practice of foreign-invested company. Bejing. BJ: Law Press.

Xu. (2011). The new development and predicament of Chinese laws concerning foreign investments. Western Legal Review, 2, 56-68.

Ye. (2010). The practical judicial explanation-On the "Provisions on Various Issues Concerning the Trial of Cases Involving Disputes Relating to Foreign Invested Enterprises (1)". China Adjudication, 56, 141-150.

Ye. (2012). The transition of Chinese regulations concerning of foreign-funded enterprises. Chinese Civil and Commercial Law Net. Retrieved from http://www.chinalawinfo.com/LawOnline/ArticleFullText.aspx? ArticleId $=73836 \&$ listType $=0$

\section{Notes}

Note 1. The amended Company Law of the People's Republic of China was adopted at the 18th session of the Standing Committee of the Tenth National People's Congress of the People's Republic of China on October 27, 2005, and was promulgated and came into force as of as of the day of January 1, 2006.

Note 2. Promulgated by the State Council on September 20, 1983. Amended by the State Council on January 15, 1986 and December 21, 1987, and amended the latest by the State Council according to the Decision of the State Council on Amending the Regulations for the Implementation of the Law of the People's Republic of China on Sino-foreign Joint Ventures on July 22, 2001.

Note 3. Adopted at the 1487th session of the Adjudication Committee of the Supreme People's Court of the People's Republic of China on May 17, 2010, promulgated on August 5, 2010 and came into force as of the day of August 16, 2010.

Note 4. Adopted at the 1382nd meeting of the Adjudication Committee of the Supreme People's Court on March 27, 2006, promulgated and came into force as of the day of May 9, 2006.

\section{Copyrights}

Copyright for this article is retained by the author(s), with first publication rights granted to the journal.

This is an open-access article distributed under the terms and conditions of the Creative Commons Attribution license (http://creativecommons.org/licenses/by/3.0/). 